\title{
USE OF 16S rRNA GENE FOR CHARACTERIZATION OF PHOSPHATE-SOLUBILIZING BACTERIA ASSOCIATED WITH CORN
}

\author{
USO DEL GEN 16S rRNA PARA CARACTERIZACIÓN DE BACTERIAS SOLUBILIZADORAS DE \\ FOSFATOS ASOCIADAS AL MAÍz
}

\author{
David Espinosa-Victoria ${ }^{1 *}$, Lucía López-Reyes ${ }^{2}$ y Aldo De La Cruz-Benítez ${ }^{1}$
}

\author{
${ }^{1}$ Colegio de Postgraduados, Campus Montecillo. Km. 36.5 Carr. México-Texcoco. 56230, Montecillo, Texcoco, Estado de México, México. Tel. and Fax \\ 01 (595) 951-0170. ${ }^{2}$ Instituto de Ciencias, Benemérita Universidad Autónoma de Puebla. 01622, Puebla, México. \\ *Corresponding author (despinos@colpos.mx)
}

\section{RESUMEN}

Se caracterizaron fenotípica y genotípicamente 36 cepas de bacterias solubilizadoras de fosfato (BSP), aisladas de la rizosfera y rizoplano del maíz (Zea mays L.) en diferentes estados de México. Primeramente, se evaluó la capacidad de cada cepa para solubilizar fosfato, empleando fosfato tricálcico como fuente de fósforo en el medio de cultivo NBRIP-BPB. También, se evaluó su capacidad solubilizadora de fosfato pero adicionando al medio el amortiguador de pH MES (2-[Morfolino] ácido etanosulfónico). El análisis de patrones de restricción de ARN ribosomal amplificado (ARDRA) fue empleado para el estudio de la diversidad genética. A partir de la matriz generada, se construyó un dendrograma por el método UPGMA. El gen 16S rRNA de las cepas BUAP29, BUAP36 y CP08 fue amplificado, clonado y secuenciado para su clasificación taxonómicamente. Las 36 cepas bacterianas presentaron diversos niveles de actividad solubilizadora de fosfato tricálcico. Solamente las cepas BUAP33, BUAP17 y BUAP21 no presentaron el típico halo de solubilización cuando se adicionó al medio el amortiguador MES. El análisis de los patrones ARDRA así como el dendrograma mostraron una gran diversidad genética entre las 36 BSP analizadas, donde solamente las cepas BUAP36 y BUAP15 exhibieron $100 \%$ de similitud. El alineamiento de las secuencias del gen 16S rRNA de las cepas CP08, BUAP29 y BUAP36 presentó $99 \%$ de identidad con las secuencias de Advenella incenata cepa R-16599 (con número de acceso AY569458.1 en NCBI), Burkholderia sp (con número de acceso AY353696 en NCBI) y Burkholderia gladioli cepa 223-1 (con número de acceso DQ355168.1 en NCBI), respectivamente. En el presente estudio se reporta por primera vez a $A$. incenata como una BSP.

Palabras clave: ARDRA, bacterias solubilizadoras de fosfato, diversidad genética, 16S rRNA.

\section{SUMMARY}

Thirty-six strains of phosphate-solubilizing bacteria (PSB) isolated from the rhizosphere and rhizoplane of corn (Zea mays L.) crops in different states of México were subjected to phenotypic and genotypic characterization. The phosphate-solubilizing activity of each strain was first evaluated using tricalcium phosphate as the phosphorus source in the NBRIP-BPB culture medium. Phosphatesolubilizing capacity was also evaluated by adding the $\mathrm{pH}$ buffering agent MES (2-[Morpholine] ethanosulfonic acid) to the growth me- dium. Amplified ribosomal RNA restriction pattern analysis (ARDRA) was used to evaluate the genetic diversity. From the data matrix obtained, a dendrogram was built using the UPGMA method. The 16S rRNA gene of the BUAP29, BUAP36 and CP08 strains was amplified, cloned and sequenced for taxonomic identification. The 36 bacterial strains exhibited different levels of tricalcium phosphate solubilizing activity. Only BUAP33, BUAP17 and BUAP21 strains did not show the typical solubilization halo when the MES buffering agent was added to the growth medium. The analysis of ARDRA patterns as well as the dendrogram exhibited a large genetic diversity among the 36 PSB analyzed, with BUAP36 and BUAP15 strains showing $100 \%$ similarity. The 16S rRNA gene sequence alignment of CP08, BUAP29 and BUAP36 strains showed 99 $\%$ identity with the sequences of Advenella incenata strain R-16599 (NCBI accession number AY569458.1), Burkholderia sp (NCBI accession number AY353696) and Burkholderia gladioli strain 223-1 (NCBI accession number DQ355168.1), respectively. In this study the $A$. incenata strain is reported as a PSB for the first time.

Index words: ARDRA, genetic diversity, phosphate-solubilizing bacteria, 16S rRNA.

\section{INTRODUCTION}

Phosphorus is one of the essential nutrients for plant growth and the absence of this element in the soil could limit plant development (Igual et al., 2001). It is well known that a large proportion of the inorganic phosphorus added to the soil as fertilizer is not available for plants because of its rapid immobilization (Mehta and Nautiyal, 2001).

The existence of soil microorganisms (bacteria, actinomycetes and some fungi) that solubilize soil-precipitated or soil-attached phosphate has been reported previously (Reyes et al., 2001). Most of the reported phosphatesolubilizing bacteria (PSB) belong to Pseudomonas, Bacillus, Enterobacter, Rhizobium, Mesorhizobium, Burkholderia, Azotobacter, Azospirillum and Erwinia genera, and the following are the most widely studied 
species: Pseudomonas sp. (Illmer and Shinner, 1992), $P$. putida (Kumar et al., 2000), P. aeruginosa, $P$. corrugata, P. stutzeri (Vázquez et al., 2000), P. fluorescens (Rodríguez and Fraga, 1999), P. cepacia (Bar-Yosef, 1996), Bacillus firmus (Banik and Dey, 1982), B. amyloliquefaciens, B. atrophaeus (Vázquez et al., 2000), Enterobacter agglomerans (Laheurte and Berthenlin,1998), E. taylorae, E. aerogenes, E. asburiae (Vázquez et al., 2000), Rhizobium leguminosarum (Halder et al., 1990), R. meliloti (Halder and Chakrabartty, 1993), Mesorhizobium mediterraneum (Peix et al., 2001), Azospirillum halopraeferans (Seshadri et al., 2000), Burkholderia cepacia (Rodríguez and Fraga, 1999), Erwinia herbicola (Liu et al., 1992), Azotobacter chrococcum (Kumar et al., 2000) and Pantoea agglomerans (Son et al., 2006).

The phosphate solubilizing activity of these microorganisms has been demonstrated through their growth on culture media supplemented with tricalcium phosphate, dicalcium phosphate, hydroxyapatite, phosphoric rock and other minerals containing insoluble $\mathrm{P}$ as sole phosphate source (Igual et al., 2001). The phosphate-solubilizing activity is qualitatively assessed by the ability to form solubilization halos (light zones) around the microbial colonies (Mikánova and Nováková, 2002), when they grow on plates of distinct culture media such as Pikovskaya agar, NBRIP medium (Nautiyal, 1999) and NBRIP-BPB medium (Mehta and Nautiyal, 2001). These culture media contain bromophenol blue which is a $\mathrm{pH}$ change indicator due to the phosphate-solubilizing activity. The halo area is equivalent to the phosphate solubilizing activity measured by other techniques based on direct or indirect quantification of soluble phosphate, such as spectrophotometry and Olsen method (Rodriguez and Fraga, 1999). Several phosphate-solubilizing mechanisms have been described, including the production of 1) organic acids, $\mathrm{H}^{+}$and $\mathrm{HCO}_{3}^{-}$ions, 2) polysaccharides (Goenadi et al., 2000); and 3) phosphatase enzymes, mainly acid phosphatases (Rodriguez et al., 2000).

The analysis of soil microbial diversity is relevant to define soil quality (Alkorta et al., 2003). Polyphasic taxonomical studies, which include phenotypic, genetic and phylogenetic information, have been widely used in microbial diversity studies (Vandamme et al., 1996). Regarding genetic and phylogenetic characterizations, molecular techniques such as gene sequencing have been used (Eisen, 1995). The sequence of the 16S rRNA gene has been widely used as phylogenetic marker in microbial ecology (Ludwig et al., 1998), since the extent of divergence in the sequence of this gene provides an estimate of the phylogenetic distance existing between different species (Igual et al, 2001). Based on polyphasic taxonomical studies, new PSB species have been identified, such as $P$. rhizospharae (Peix et al., 2003), P. lutea (Peix et al., 2004) and Microbacterium ulmi (Rivas et al., 2004). In the present work, 36 PSB strains isolated from corn (Zea mays L.) crops of different regions of México were phenotypically and genetically analyzed in order to know their tricalcium phosphate-solubilizing capacity, as well as the genetic diversity using the amplified DNA restriction analysis of the 16S rRNA gene (ARDRA). The strains with the greatest solubilizing capacity were classified taxonomically based on the 16S rRNA gene sequence.

\section{MATERIALS AND METHODS}

Biological material. From the 36 phosphatesolubilizing strains used, 19 belong to the collection of the Plant-Microorganism Molecular Interaction Laboratory of the Colegio de Postgraduados (labeled as CP) and 17 strains belong to the collection of the Soil Microbiology Laboratory of the Benemérita Universidad Autónoma de Puebla, (labeled as BUAP). All the strains were isolated from the rhizosphere and rhizoplane of maize plants during different seasons at different locations in México (Table 1). After isolation and purification, the strains were preserved in glycerol at $-71{ }^{\circ} \mathrm{C}$ until needed.

Phosphate-solubilizing activity. Phosphatesolubilizing activity was determined on Pikovskaya (1948) culture plates. Each strain was streaked out in duplicate, and incubated at $27{ }^{\circ} \mathrm{C}$ for $72 \mathrm{~h}$. The halo formation around the bacterial colony was considered as the indicator of phosphate-solubilizing activity (Seshadri et al., 2000). Strains were spread on Pikovskaya plates for five consecutive times to confirm the phosphate-solubilizing activity (Igual et al., 2001). Strain CP99, which lacks phosphate-solubilizing activity, was used as a negative control.

Phosphate-solubilizing efficiency. The in vitro phosphate-solubilizing capacity of each strain was determined on NBRIP-BPB medium containing bromphenol blue as a $\mathrm{pH}$ indicator (Mehta and Nautiyal, 2001). Two variants of the NBRIP-BPB medium were used: NBRIP with $\mathrm{Ca} 3$ $\left(\mathrm{PO}_{4}\right)_{2}$ as sole $\mathrm{P}$ source (Medium 1), and NBRIP-BPB medium containing $\mathrm{Ca}_{3}\left(\mathrm{PO}_{4}\right)_{2}$ plus MES buffering agent (Medium 2). A $10 \mu \mathrm{L}$ suspension of each strain containing $10^{7}$ cells $\mathrm{mL}^{-1}$ was sown in triplicate, and incubated at $28{ }^{\circ} \mathrm{C}$ for $72 \mathrm{~h}$. The solubilization efficiency (E) was determined by measuring the halo diameter (HD) and the colony diameter (CD), to obtain the relation of $\mathrm{HD} / \mathrm{CD} x$ 100 (Seshadri et al., 2000).

DNA isolation. Bacterial strains were cultivated in 10 $\mathrm{mL}$ of Luria-Bertani broth (LB) at $29{ }^{\circ} \mathrm{C}$ in agitation for $18 \mathrm{~h}$. One milliliter of the culture was placed in 
microtubes and pelleted by centrifuging at $12300 x \mathrm{~g}$ for 2 min. For total DNA extraction, the FastDNA kit ( ${ }^{\circ} B i o$ 101) was used following the manufacturer's instructions. The DNA extracted from each strain was visualized by electrophoresis in $1 \%$ agarose gels using TAE $1 \mathrm{X}$ buffer containing ethidium bromide. Observations were carried out using the UV Eagle Eye ${ }^{\mathrm{TM}}$ (Stratagene ${ }^{\circledR}$ ) photo documentation system.

16S rRNA gene amplification. The region of the $16 \mathrm{~S}$ ribosomal gene (rRNA) of the DNA extracted from each bacterial strain was amplified by the polymerase chain reaction (PCR). The reagent mixture was prepared with the fD1 and rD1 primers (Weisburg et al., 1991), 1U of Taq polymerase enzyme and $1 \mathrm{X}$ reagent buffer (Promega ${ }^{\circledR}$ ). The reagent mixture was incubated in a Hybaid PCR Ex- press thermocycler (Thermohybaid, California, USA). The amplification conditions used for the PCR were as indicated by Weisburg et al. (1991). PCR products were observed by electrophoresis in agarose gels as described above.

Amplified ribosomal RNA pattern analyses (ARDRA). The amplified products of the 16S rRNA gene were subject to digestion with the following restriction enzymes: DdeI, HaeIII, Hhal, HindI and MspI. Five U of each restriction enzyme were used per $5 \mu \mathrm{L}$ of amplified product and the mixture was incubated at $35{ }^{\circ} \mathrm{C}$ during 3 $\mathrm{h}$. The restriction fragments obtained were subjected to electrophoresis on a $3 \%$ agarose gel in TAE 1X buffer containing ethidium bromide and observed as described above.

Table 1. Phosphate-solubilizing efficiency of the phosphate-solubilizing bacteria.

\begin{tabular}{|c|c|c|c|c|}
\hline Strain & Origin & Biochemical identification & Medium 1 & Medium 2 \\
\hline BUAP06 & Iquimita, Puebla & Burkholderia gladioli & $166.67 \mathrm{ijk}$ & $141.33 \mathrm{st}$ \\
\hline BUAP15 & San Antonio Virreyes, Puebla & Burkholderia cepacia & $220 \mathrm{~cd}$ & 196.67 jklmn \\
\hline BUAP16 & San Antonio Virreyes, Puebla & Burkholderia cepacia & $160 \mathrm{jklm}$ & 158.33 opqr \\
\hline BUAP19 & Acajete, Puebla & Burkholderia gladioli & $256.67 \mathrm{bc}$ & $176.67 \mathrm{mnopq}$ \\
\hline BUAP21 & Acajete, Puebla & Burkholderia gladioli & $213.33 \mathrm{ef}$ & $\mathrm{nt}$ \\
\hline BUAP29 & Huasca, Hidalgo & Burkholderia gladioli & $326.67 \mathrm{a}$ & $258.33 \mathrm{bcd}$ \\
\hline BUAP36 & Huasca, Hidalgo & Burkholderia cepacia & $213.33 \mathrm{ef}$ & 266.7 hijkl \\
\hline BUAP02 & Tenextepec, Puebla & Enterobacter cloacae & $330 \mathrm{a}$ & $300 \mathrm{a}$ \\
\hline BUAP22 & San José Teacalco, Puebla & Enterobacter cloacae & $280 \mathrm{~b}$ & $280 \mathrm{ab}$ \\
\hline BUAP30 & Ixmiquilan, Hidalgo & Enterobacter cloacae & $260 \mathrm{bc}$ & 250 cde \\
\hline BUAP32 & Huasca, Hidalgo & Enterobacter cloacae & $186.67 \mathrm{ghi}$ & $176.67 \mathrm{mnopq}$ \\
\hline BUAP37 & Mixquiahuala, Puebla & Enterobacter cloacae & $253.33 \mathrm{c}$ & 216.67 ghij \\
\hline $\mathrm{CP} 07$ & Villadiego, Guanajuato & Pseudomonas fluorescens & 180 hij & $176.6 \mathrm{mnopq}$ \\
\hline CP04 & Pabellón de Arteaga, Aguascalientes & Pasteurella multocida & $150 \mathrm{klmn}$ & $141.67 \mathrm{rstu}$ \\
\hline CP16 & Villadiego, Guanajuato & Panteoa agglomer & $141 \mathrm{mn}$ & $110 \mathrm{uv}$ \\
\hline $\mathrm{CP} 24$ & Villadiego, Guanajuato & Pantoea agglomer & $130 \mathrm{n}$ & $110 \mathrm{v}$ \\
\hline CP15 & Villadiego, Guanajuato & Panteoa agglomer & $126.67 \mathrm{n}$ & 118.33 tuv \\
\hline CP34 & Pabellón de Arteaga, Aguascalientes & No identified & $245 \mathrm{c}$ & $228 \mathrm{ef}$ \\
\hline $\mathrm{CP} 25$ & Santa Isabel de Ajuno, Michoacán & No identified & $132 \mathrm{n}$ & $115 \mathrm{v}$ \\
\hline CP5 & Villadiego, Guanajuato & No identified & $260 \mathrm{bc}$ & 225 efgh \\
\hline CP19 & Pabellón de Arteaga, Aguascalientes & No identified & 180 hij & 158.33 opqr \\
\hline CP10 & Pabellón de Arteaga, Aguascalientes & No identified & $170 \mathrm{ijk}$ & $146.67 \mathrm{rs}$ \\
\hline CP11 & Villadiego, Guanajuato & No identified & $136.67 \mathrm{mn}$ & $110 \mathrm{v}$ \\
\hline CP12 & Villadiego, Guanajuato & No identified & $160 \mathrm{jklm}$ & 128.33 stuv \\
\hline
\end{tabular}

Mean values of each column with the same letter are not statistically different (Tukey, 0.05). Growth medium $1=\mathrm{NBRIP}_{-} \mathrm{BPB}$ with $\mathrm{Ca}_{3}\left(\mathrm{PO}_{4}\right)_{2} ; \mathrm{Growth}$ medium $2=$ NBRIP-BPB with $\mathrm{Ca}_{3}\left(\mathrm{PO}_{4}\right)_{2}$ plus MES buffering agent. Identified by Apilab ${ }^{\circledR}$ plus API $20 \mathrm{~N}$ and/or $20 \mathrm{NE}$; nt $=\mathrm{Not}$ tested. 
Dendrogram construction. The band patterns obtained (genomic profile) were used to generate a data matrix using the Jaccard similarity coefficient. A dendrogram was then constructed through the unweighted pair group method with arithmetic averages (UPGMA) (Sneath and Sokal, 1973), using the NTSYS-pc V1.8 program (Rohlf, 1993) to determine the genetic diversity of PSB groups.

$16 S$ rRNA gene partial sequencing. Sequencing was only carried out for the BUAP29, BUAP36 and CP08 strains. A TA Cloning $\AA$ Kit (Roche $®)$ and the pCR $\circledast 2.1$ ligation vector were used to clone PCR products of approximately $1.5 \mathrm{~kb}$ of the $16 \mathrm{~S}$ rDNA gene of each of the three strains. Sequencing was carried out using the universal and reverse m13 pUC oligonucleotides by automated DNA fluorescent sequencing. The sequence was obtained from the Synthesis Unit of the Biotechnology Institute of the Universidad National Autónoma de México (UNAM).

16S rRNA gene partial sequence analysis. The partial sequences of the 16S rRNA genes of the BUAP29, BUAP36 and CP08 strains were compared to sequences reported in the NCBI (National Center for Biotechnology Information) databases using the nucleotide-nucleotide BLASTn program (Altschul et al., 1997).

\section{RESULTS AND DISCUSSION}

\section{Phenotypic characterization of phosphate-solubilizing bacterial strains}

Solubilization efficiency. All the strains maintained their phosphate-solubilizing activity after being re-sown five consecutive times in Pikovskaya medium (Igual et al., 2001). Table 1 shows the strain solubilization efficiency assessed with different $\mathrm{P}$ sources.

All bacteria analyzed presented phosphate-solubilizing activity although to different levels on the NBRIP-BPB medium carrying $\mathrm{Ca}_{3}\left(\mathrm{PO}_{4}\right)_{2}$ (Medium 1) as sole $\mathrm{P}$ source, suggesting that these strains may be used to generate soluble $\mathrm{P}$ in soils containing tricalcium phosphates in their minerals (Goenadi et al., 2000).

It has been demonstrated that there are at least two $\mathrm{P}$ solubilization mechanisms: production of organic acids, such as the citric, malic, oxalic, glutamic acids (Dirk and Lesas, 2000), lactic, succinic, isovaleric, isobutyric, acetic acid (Rodríguez and Fraga, 1999), and gluconic acid (Babu-Khan et al., 1995), among others, and the production of phosphatase enzymes (Yang et al., 1997), especially acid phosphatase (Rodríguez et al., 2000).
Most strains showed a lower phosphate-solubilizing efficiency when the medium was supplemented with MES buffering agent. The BUAP33, BUAP17 and BUAP21 strains did not show the typical solubilization halo in the culture medium supplemented with the MES buffering agent. The MES buffering agent prevents $\mathrm{pH}$ modification of the medium surrounding the bacterial colony; therefore, the phosphate-solubilizing activity could be due to a mechanism different to organic acid production (Mehta and Nautiyal, 2001). Gyaneshwar et al. (1998) isolated from alkaline vertisol two PSB strains using conventional screening media could not release phosphorus from alkaline Indian vertisol soils supplemented with carbon and nitrogen sources. They found that the two PSBs could solubilize both rock phosphate and di-calcium phosphate inunbuffered media but failed to solubilize rock phosphate in buffered media. The organic acids secreted by these PSBs were 20-50 times less than that required to solubilize phosphorus from alkaline soil.

Thakuria et al. (2004) have demonstrated that there is no statistically significant relation between the $\mathrm{pH}$ increase in the Pikovskaya broth and its soluble P content, which indicates that the solubilizing activity may occur of because of factors other than the production of organic acids. In another study, Johri et al. (1999) reported an increase in the solubilizing activity by the NBR14 and NBR17 strains cultured in NBRIP medium when $\mathrm{NaCl}$ was replaced by $\mathrm{CaCl}_{2}$ or $\mathrm{KCl}$ and incubated at $30{ }^{\circ} \mathrm{C}$. Also they found an increase in the $\mathrm{P}$ solubilizing activity when bacterial strains where incubated at $37{ }^{\circ} \mathrm{C}$ rather than at $30^{\circ} \mathrm{C}$. These data clearly indicate the influence of the salt source and the incubation temperature on the phosphate-solubilizing activity on the NBRIP medium. Several studies have shown that the composition of the medium affects the phosphate-solubilizing activity (Gibson and Mitchell, 2004) as well as the type of soil (Nautiyal et al., 2000), and the location from where the bacteria were isolated (Coenye and Vyame, 2003).

The BUAP29, BUAP36 and CP08 strains showed high P solubilizing activity in both media (Table 1), and were therefore selected for genetic taxonomic characterization up to the species level by $16 \mathrm{~S}$ rRNA gene sequencing.

\section{Genetic diversity of PSB strains}

The restriction patterns of the amplified fragments of the 16S rRNA gene of the 34 strains were different from each other (Figure 1), except BUAP36 and BUAP15 which were identical. Digestion carried out using the enzyme DdeI, showed 14 different patterns, while the enzymes Hhal and Himf exhibited 15; the enzymes HaeIII 10 and $M s p I$ gave nine patterns. The presence of different 
patterns when using the same restriction enzymes indicates that there are differences within the sequence of the 16S rRNA gene and therefore, there exists a large genetic diversity in the studied population. Analysis of variation of the ribosomal $16 \mathrm{~S}$ gene allows the inference of the phylogenetic relationships among taxonomically relatively close and distant organisms (Eisen, 1995; Ludwig et al., 1998). The dendrogram (Figure 2) indicates the existence of a great genetic diversity of PSB. There were no bacterial isolates with the same genetic pattern, except for BUAP36 and BUAP15 strains, which showed the same pattern in the profiles obtained with the five restriction enzymes and had $100 \%$ similarity, thus suggesting that these two strains may belong to the same taxon. Amos and Harwoud (1998) mention that there could be many factors related to the genetic diversity in a population, for instance, the site of origin of the strains as well as the associated crop. It seems that such factors may have influenced the PSB population in the present study.

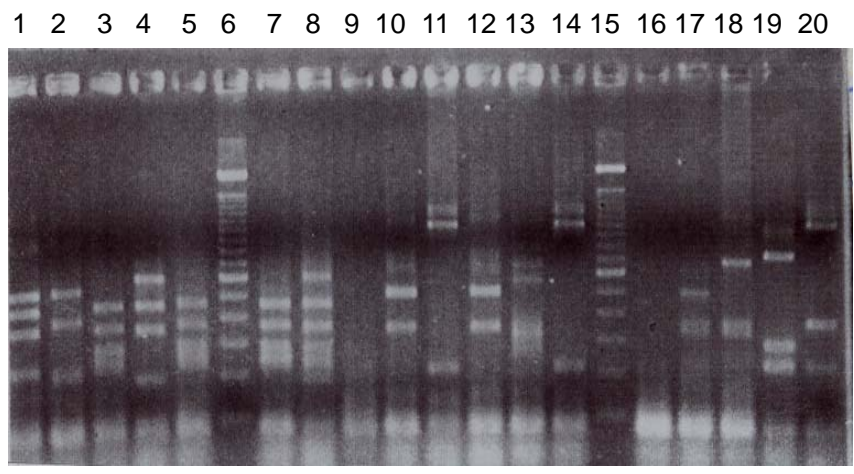

Figure 1. Electrophoretic profile of the 16S rRNA gene restriction analysis (ARDRA) obtained from the restriction of the amplified gene16S rRNA with Dde enzyme. Strains analyzed per lane: 1, CP14; 2 CP 17;3 BUAP 01; 4, CP08; 5, BUAP 32; 6, 1kb plus Marker; 7, CP12; 8 CP10; 9 BUAP 07; 10, CP15; 11, BUAP 19; 12, BUAP 21; 13, BUAP 16; 14, CP06; 15 1Kb Marker; 16, BUA9 31; 17, CP 17; 18, CP18; 19, BUAP 21; 20, CP 21.

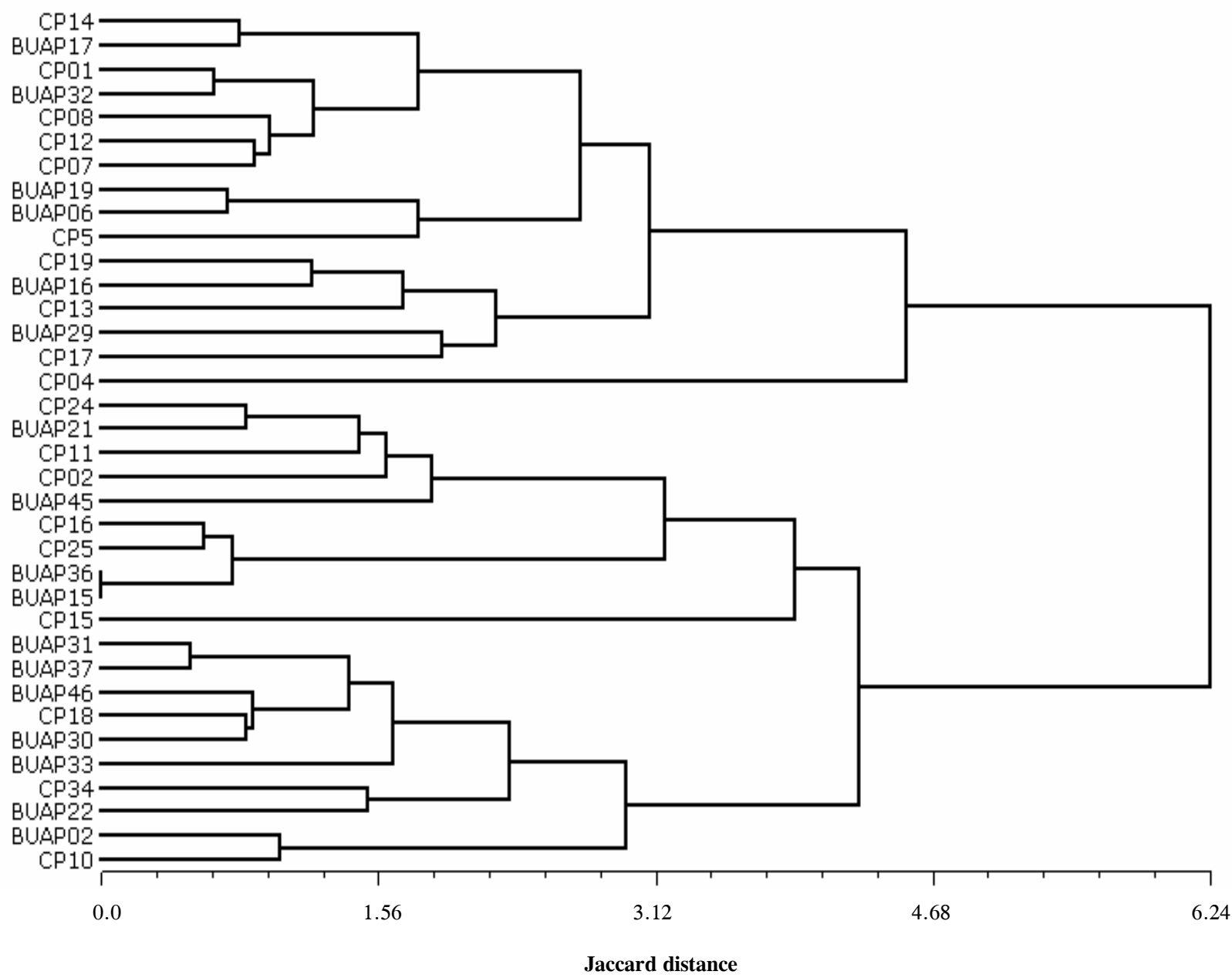

Figure 2. Dendrogram of phosphate solubilizing bacteria strains, based on the partially PCR-amplified 16S rRNA gene restriction patterns analysis. 
Taxonomic classification. The sequences of the $16 \mathrm{~S}$ rRNA gene of the BUAP29 and BUAP36 strains showed $99 \%$ identity with the sequence of the 16S rRNA gene reported in the Genbank for Burkholderia sp (accession number AY353696 in NCBI), Burkholderia gladioli strain 223 gr-1 (NCBI: DQ355168.1) and the CP08 strain showed $99 \%$ identity to Advenella incenata strain R-1659 (NCBI: AY569458.1). These results differ from the classification obtained with biochemical testing using the API 20NE and API 20N system; BUAP 29 was identified as Burkholderia gladioli and BUAP 36 as Burkholderia cepacia. The CP08 strain has not been identified based on biochemical testing with API 20NE, and therefore may be classified as Advenella incenata, a poorly studied species. Coenye et al. (2005) suggested it as a new species, belonging to the family of the Alcaligenacea, subclass- $\beta$ of Proteobacteria. These results suggest the need to carry out cloning and sequencing of the $16 \mathrm{~S}$ rRDN gene of the remaining strains in order to achieve a correct taxonomic classification (Pace, 1997), and emphasize the importance of carrying out polyphasic taxonomy studies. Igual et al. (2001) mentioned some useful molecular techniques for isolation and efficient identification of PSBs (16S rRNA sequencing, LMW RNA profiles, TP-RADP and rep-PCR fingerprinting), and Peace (1996) described a method to obtain strain-specific DNA probes.

In the present study Advenella incenata is reported for the first time as a phosphate-solubilizing microorganism due to its capacity to solubilize tricalcium phosphate in NBRIP-BPB culture medium.

\section{CONCLUSIONS}

Thirty six strains analyzed solubilized tricalcium phosphate when used as the sole P source in the NBRIPBPB culture medium. Most of the strains showed a decrease in their phosphate-solubilizing efficiency when MES buffering agent was added to the NBRIP-BP medium.

BUAP33, BUAP17 and BUAP21 strains did not show the typical solubilization halo in the culture medium supplemented with the MES buffering agent, because the buffering agent prevented the $\mathrm{pH}$ modification of the medium surrounding the bacterial colony. Therefore, the phosphate-solubilizing efficiency could be due to a different mechanism for organic acid production.

The ARDRA analysis indicates the existence of a large genetic diversity in the studied population, and the dendrogram only grouped the BUAP36 and BUAP 15 strains with $100 \%$ similarity. No correlation was found between
ARDRA patterns and biochemical taxonomic classification.

The analysis of the 16S rDNA gene partial sequences at Genbank showed $99 \%$ similarity, classifying BUAP29 strain as Burkholderia sp, BUAP36 strain as Burkholderia gladioli, and CP08 strain as Advenella incenata.

This study reports for the first time the species $A d$ venella incenata as phosphate-solubilizing bacteria.

\section{ACKNOWLEDGEMENTS}

To M.Sc. Moisés Carcaño for the donation of BUAP strains, Q.F.B. Rosalba Palma Sánchez and Dr. Teresa Terrazas for their support in the construction of the dendrograma, as well as to Dr. Jesús Caballero Mellado and Lourdes Martinez Aguilar for their support in the ARDRA assay.

\section{BIBLIOGRAPHY}

Alkorta I, I Amezaga, I Albizu, A Aizpurua, M Onaindia, V Buchner, C Garbicu (2003) Molecular microbial biodiversity assement: a biological indicator of soil health. Rev. Environ. Health 18:131-151.

Altschul S F, T L Madden, A A Schäffer, J Zhang, Z Zhang, W Millar, D J Lipman (1997) Gapped BLAST and PSIBLAST: a new generation of protein database search programs. Nucleic Acids Res. 25:3389-3402.

Amos W, J Harwoud (1998) Factors affecting levels of genetic diversity in natural populations. Philos. Trans. Royal Soc. London, Series B, Biol. Sci. 353:177-186.

Babu-Khan S, T C Yeo, W L Martin, M Duron, R D Rogers, A H Goldstein (1995) Cloning of a mineral phosphate-solubilizing gene from Pseudomonas cepacia. Appl. Environ. Microbiol. 61:972-978.

Banik S B, D Dey (1982) Available phosphate content of an alluvial soil as influenced by inoculation of some isolated phosphatesolubilizing micro-organisms. Plant and Soil 69:353-364.

Bar-Yosef B (1996) Root excretions and their environmental effects: Influence on availability of phosphorus. In: Plant Roots: The Hidden Half. Y Waisel, A Eshel, U Kafkafi (eds.) 2nd ed. Marcel Dekker. New York. pp:581-605.

Coenye T, P Vyame (2003) Diversity y significance of Burkholderia species occupying diverse ecological niches. Environ. Microbiol. 5:719:729.

Coenye T, E Vanlaere, E Samyn, E Falsen, P Larsson, P Vandamme (2005) Advanella incenata gen. nov., sp. Nov., a novel member of the Alcaligenaceae, isolated from various clinical samples. Internatl. J. Syst. Evol. Microbiol. 55:251256.

Dirk J, J Lesas (2000) Modern Soil Micobiology. Ed. Marcel Dekker. New Cork. USA. 235 p.

Eisen J A (1995) The RecA protein as a model molecule for molecular systematic studies of bacteria: comparison of trees of RecAs and $16 \mathrm{~S}$ rRNAs from the same species. J. Mol. Evol. 41:1105-1123.

Gyaneshwar P, G N Kumar, L J Parekh (1998) Effect of buffering on the phosphate-solubilizing ability of microorganisms. World J. Microbiol. Biotechn. 14:669-673. 
Gibson B R, D T Mitchell (2004) Nutritional Influences on the solubilization of metal phosphate by ericoid mycorrhizal fungi. Mycol. Res. 108:947-954.

Goenadi D H, I Sisweto, Y Sugiarto (2000) Bioactivation of poorly soluble phosphate rocks with a phosphorus-solubilizing fungus. Soil Sci. Soc. Amer. J. 64:927-932.

Halder A K, P K Chakrabartty (1993) Solubilization of inorganic phosphate by Rhizobium. Folia Microbiol. 38:325-330.

Halder A K, A K Mishara, P K Chakrabartty (1990) Solubilization of phosphatic compound by Rhizobium. Indian J. Microbiol. 30:311-314

Igual J M, A Valverde, E Cervantes, E Velázquez (2001) Phosphatesolubilizing bacteria as inoculants for agriculture: use updated molecular techniques in their study. Agronomie 21:561-568.

Illmer P, F Schinner (1992) Solubilization of inorganic phosphates by phosphate by microorganisms isolated from forest soil. Soil Biol. Biochem. 24:389-395.

Johri J K, S Surange, C Nautiyal (1999) Occurrence of salt, pH, and temperature-tolerant, phosphate-solubilizing bacteria in alkaline soils. Curr. Microbiol. 39:89-93.

Kumar V, N K Aggarwal, B P Singh (2000) Performance and persistence of phosphate solubilizing Azotobacter chroococcum in wheat rhizosphere. Folia Microbiol. 45:343-347.

Laheurte F, J Berthenlin (1998) Effect of a phosphate solubilizing bacteria on maize growth and root exudation over four levels of labile phosphorus. Plant and Soil 105:11-17.

Liu S T, L Y Lee, C Y Tai, C H Hung, Y S Chang, J H Wolfram, R Rogers, A H Goldstein (1992) Cloning of an Erwinia herbicola gene necessary for gluconic acid production and enhanced mineral phosphate solubilization in Escherichia coli HB101: nucleotide sequence and probable involvement in biosynthesis of the coenzyme pyrroloquinoline quinone. $\mathrm{J}$. Bacteriol. 174:5814-5819.

Ludwig W, R Amann, E Martinez-Romero, W Schönhuber, S Bauer, A Neef , H Schleifer (1998) rRNA base identification and detection systems for rhizobia and other bacteria. Plant and Soil 204:1-19.

Mehta S, C S Nautiyal (2001) An efficient method for qualitative screening of phosphate-solubilizing bacteria. Curr. Microbiol. 43:51-56.

Mikánova O, J Nováková (2002) Evaluation of the P-solubilizing activity of soil microorganisms and its sensitivity to soluble phosphate. Rostlinná Výroba 48:397-400.

Nautiyal C S (1999) An efficient microbiological grown medium for screening phosphate solubilizing microorganisms. Fed. Europ. Materials Soc. Microbiol. Lett. 170:265-270.

Nautiyal C, S Bhadauria, P Kumar, H Lal, R Mondal, D Verma (2000) Stress induced phosphate solubilization in bacterial isolated from alkaline soils. Fed. Europ. Materials Soc. Microbiol. Lett. 182:291-296.

Pace N R (1996) New perspective in the natural microbial world: molecular microbial ecology. Amer. Soc. Microbiol. News 62:463-470.

Pace N R (1997) A molecular view of microbial diversity and the biosphere. Science 276:734-740.

Peix A, R Rivas, P F Mateos, E Martínez-Molina, C RodríguezBarrueco, E Velázquez (2003) Pseudomonas rhizosphaerae sp. nov., a novel species that actively solubilizes phosphate in vitro. Internatl. J. Syst. Evol. Microbiol. 53:2067-2072.
Peix A, R Rivas-Boyero, P Mateos, C Rodriguez-Barrueco, E Martínez-Molina, E Velázquez (2001) Growth promotion of chickpea and barley by a phosphate solubilizing strain of Mesorhizobium mediterraneum under growth chamber conditions. Soil Biol. Biochem. 33:103-110.

Peix A, R Rivas, I Santa-Regina, P Mateos, E Martínez-Molina, C Rodriguez-Barrueco, E Velázquez (2004) Pseudomonas lutea sp. nov., a novel phosphate-solubilizing bacterium isolated from the rhizosfere of grasses. Internatl. J. Syst. Evol. Microbiol. 54:847-850.

Pikovskaya R I (1948) Mobilization of phosphorus in soil connection with the vital activity of some microbial species. Mikrobiologia 17:362-370.

Reyes I, R Baziramakenga, L Bernier, H Antoun (2001) Solubilization of phosphate rocks and minerals by a wild-type strain y two UV-induced mutants of Penicillium rugulosum isolate. Soil Biol. Biochem. 33:1741-1747.

Rivas R, M E Trujillo, M Sánchez, P F Mateos, E Martínez-Molina, E Velásquez (2004) Microbacterium ulmi sp. Nov. a xilanolytic, phosphate-solubilizing bacterium isolated from sawdust of Ulmus nigra. Internatl. J. Syst. Evol. Microbiol. 54:513:517.

Rodríguez H, R Fraga (1999) Phosphate solubilizing bacteria and their role in plant growth promotion. Biotechnol. Adv. 17:319 339.

Rodríguez H, G M Rossolini, T González, J Li, B RGlick (2000) Isolation of a gene from Burkholderia cepacia IS-16 encoding a protein that facilitates phosphatase activity. Curr. Microbiol 40:362-366

Rohlf F J (1993) NTSYS-pc v. 1.8. Numerical taxonomy and multivariate analysis system. Applied Biostatistics Inc. Setauket, NY. $191 \mathrm{p}$.

Son H J, G T Park, M S Cha, M S Heo (2006) Solubilization of insoluble inorganic phosphate by a novel salt- and $\mathrm{pH}$-tolerant Pantoea agglomerans R-42 isolated from soybean rhizosphere. Biores. Technol. 97:204-210.

Sneath P H A, R R Sokal (1973) Numerical Taxonomy: The Principles and Practice of Numerical Classification. Ed. W H Freeman. San Francisco. 573 p.

Seshadri S, R Muthukumarasamy, R Lakshminarasimhan, C Lakshiminarasimhan, S Ignacimuthu (2000) Solubilization of inorganic phosphates by Azospirillum halopraeferans. Curr. Sci. 79:565-567

Thakuria D, N C Talukdar, C Goswami, S Hazarika, R C Boro, M Khan (2004) Characterization and screening of bacteria from rhizosphere of rice grown in acidic soils of Assam. Curr. Sci. 86:978-995.

Vandamme P, B Pot, M Gillis, P De Vos, K Kersters, J Swings (1996) Polyphasic taxonomy, a consensus approach to bacterial systematics. Microbiol. Mol. Biol. Rev. 60: 407-438.

Vázquez P, G Holguin, M E Puente, A Lopez-Cortes, Y Bashan (2000) Phosphate-solubilizing microorganisms associated with the rhizosphere of mangroves in a semiarid coastal lagoon. Biol. Fertil. Soils 30:460-468

Weisburg W, S Barns, D Pelletier, D Lane (1991) 16S Ribosomal DNA amplification for phylogenetic study. J. Bacteriol. 173:697-703.

Yang Y, W Shipton, P Reddell (1997) Effects of phosphorus supply on in vitro growth and phosphatase activity of Frankia isolates from Casuarina. Plant and Soil 189:75-79. 